\title{
Soil diversity and properties in mountainous subtropical areas, in Sierra Sur de Oaxaca, Mexico
}

\author{
N. E. García Calderón¹, A. Ibáñez Huerta1, G. Alvarez Arteaga1, \\ P. V. Krasilnikov ${ }^{1,2}$, and A. Hernández Jiménez ${ }^{3}$ \\ ${ }^{1}$ Lab. Edafología, Facultad de Ciencias, UNAM, 04510, Mexico City, D.F., Mexico \\ (e-mail: negc@hp.fciencias.unam.mx); ${ }^{2}$ Institute of Biology, Karelian Research Centre \\ RAS, 185610, Petrozavodsk, Russia; and ${ }^{3}$ Instituto Nacional de Ciencias Agrícolas \\ (INCA), Havana, Cuba. Received 18 October 2004, acepted 13 June 2005.
}

\begin{abstract}
García Calderón, N. E., Ibáñez Huerta, A., Alvarez Arteaga, G., Krasilnikov, P. V. and Hernández Jiménez, A. 2006. Soil diversity and properties in mountainous subtropical areas, in Sierra Sur de Oaxaca, Mexico. Can. J. Soil Sci. 86: 61-76. Agroforestry is a new practice of sustainable soil use in the mountainous Sierra Sur de Oaxaca area of Mexico. Coffee is also a common cash crop grown in the region. The objective of this study was to investigate the pedodiversity in the area. Soil development is very complex, and is influenced by slope parameters and parent materials. Several soil groups are found in the area investigated: Alisols, Umbrisols, and Cambisols. Morphology, chemical properties, and mineralogical composition of the clay fraction of these soils were studied. The soils vary in the extent of weathering, morphology, and chemical properties, which are important to farming in the area. Most of the soils have heterogeneous parent material. The distribution of major soil types of the area is related to mass movement along the slopes, both past and present. The studied soils represent a chronosequence from unleached and unweathered Cambisols to Alisols, characterized by strong clay illuviation and dominance of kaolinite and gibbsite in clay fraction. A mosaic of landslides and gullies of various ages, formed by catastrophic events such as earthquakes and hurricanes, form the pedodiversity of the area studied.
\end{abstract}

Key words: Landslides, chronosequence, pedodiversity, Cambisols, Umbrisols, Alisols

García Calderón, N. E., Ibáñez Huerta, A., Alvarez Arteaga, G., Krasilnikov, P. V. et Hernández Jiménez, A. 2006. La diversité des sols et ces propriétés dans la zone subtropicale montagneuse de la Sierra Madre Del Sur de Oaxaca au Mexique. Can. J. Soil Sci. 86: 61-76. L'agro-foresterie est une nouvelle pratique de l'usage sustentateur des sols dans les montagnes de la Sierra Madre del Sur de Oaxaca au Mexique. La culture du café est aussi une pratique rentable dans la région. L'objectif de cette étude a été d'investiguer la pédodiversité de la zone d'étude. Le développement du sol est très complexe et est influencé par les paramètres de l'inclinaison et par la composition d'origine. Plusieurs groupes de sol sont présents dans l'aire d'investigation : Alisoles, Umbrisoles et Cambisoles. La morphologie, les propriétés chimiques et la composition minérale de la portion argileuse de ces sols ont été étudiées. Les sols de la ferme varient selon : le climat des saisons, la morphologie et les propriétés chimiques (importantes pour l'affermage «l'agriculture farming »dans l'aire d'étude). La majorité des sols représente une absence d'uniformité de leur composition d'origine. La distribution des types de sol sur le territoire de la ferme est due en grande partie au mouvement de masse, le long des inclinaisons dans une période antérieur et présente. L'étude des sols présente une séquence chronologique qui va des Cambisols non lixivés et non méteorisé aux Alisols, caractérisés par une argile forte en illuviation dominé principalement de kaolinite et gibsite. Une mosaïque de terrains glissants et de précipices de différents âges, formée par des catastrophes, tremblements de terre et ouragans, forme la pédodiversité de la zone étudiée.

Mots clés: Terrains glissant, pédodiversité, Alisols, Umbrisols, Cambisols

The diversity of soils [or pedodiversity - a term coined by McBratney (1992)] is believed to be a major characteristic of landscape sustainability (Krasilnikov 2001). Diverse soil properties provide a wide spectrum of habitats for terrestrial plants and soil organisms. Also, diverse soils decrease the risks for agriculture, since at least some soils retain their productivity in excessively moist or dry years, or after agroecosystem disturbance (McBratney 1992; Fuentes Romero et al. 2002). Mountainous regions are characterised by high soil diversity (Feldman et al. 1991). This is mainly due to the complexity of soil-forming conditions (Homann et al. 1995; Hunckler and Schaetzl 1997) and mass movement in such areas. Transport of soil material along the slope leads to continuous renewal of the upper part of the soil profile (Graham et al. 1990). The intensity of this transport depends on the slope angle, surface vegeta- tion, and internal soil properties. Little is known about the dynamics of soil mosaics formed by slope processes. Most of the studies concentrate on a dualistic model, comparing soils formed on ancient and younger surfaces (e.g., Graham and Buol 1990). Few studies deal with soil development on a cronosequence of exposed surfaces (Sparling et al. 2003; Wilcke et al. 2003), mainly for a short temporal range. However, exposed surfaces, especially landslides, can provide valuable information on soil evolution (Huggett 1998). Landslides of various ages may indicate different stages of soil development. Thus, in mountainous regions affected by continuous slope processes, one can expect the presence of a mosaic of soils differing in the grade of their maturity.

Abbreviations: CEC, cation exchange capacity 
We studied the soils in the mountainous coffee-growing region of Oaxaca State, Mexico, a region known for its high pedodiversity (García Calderon et al. 2000; Alfaro Sánchez 2004). We hypothesised that the diversity of soils in the study area is controlled mainly by spatial organisation of the surfaces of various ages. We had two main objectives of the study: (1) to characterise the soils of the mountains of Sierra Sur de Oaxaca, an area still poorly studied, (2) to confirm that a mosaic of soils in the area studied constitutes a chronosequence of profiles formed on exposed surfaces.

\section{MATERIALS AND METHODS}

The research was conducted at the coffee-growing farm, Finca Sinai, Oaxaca State, Mexico (Fig. 1). The study area is situated at $16^{\circ} 07^{\prime} 41.5^{\prime \prime} \mathrm{N}$ and $97^{\circ} 06^{\prime} 12.9^{\prime \prime} \mathrm{W}$. This region is a typical landscape of the southwestern escarpment of the Sierra Sur de Oaxaca Mountains, the system formed by a tectonic uplift in the Miocene (Morán et al. 1996; CentenoGarcía 2004); minor uplifts also occurred in the Pliocene and even the Quaternary. The rocks are mainly gneiss and amphibolites formed during the Paleozoic epoch, and Cenozoic granites (Hernández et al. 1996). Recent sediments of the area have been studied much less. There are mainly weathering products of igneous and metamorphic rocks, sometimes deep weathered regoliths, redistributed on the slopes by gravitation and temporal water flows (Centeno-García 2004). All the territory of the Pacific coast of Mexico is a seismically active zone (Rojas et al. 1987). The first seismic event reported in the region happened in 1460. Later, numerous earthquakes of varying intensities were observed in the 18th and 19th Centuries. The two most intensive occurred in 1784 and 1787. Several major earthquakes were reported from this area in the 20th century, the last one in 1999.

The farm Finca Sinai occurs at altitudes ranging from 700 to $1200-1300 \mathrm{~m}$ above sea level. Mountain slopes are complex, with aspect varying from northeastern to southwest and slopes reaching $40^{\circ}$. The slope surfaces are dissected by erosional processes, forming deep gullies. The majority of gullies are stable and vegetated.

The climate of the region is classified as warm humid isothermal, with annual rainfall of about 1800 to $2000 \mathrm{~mm}$ and mean annual temperature of 21 to $21.9^{\circ} \mathrm{C}$ (García 1973). The region has two main seasons - dry from December through May and wet from June through November. In the autumn, rapid air movement often provokes hurricanes, which cause treefalls, enhancing water erosion (García Calderón et al. 2000). The main agricultural practice in the region is closedcanopy coffee growing, which has been successfully used in this region for more than 150 years. The practice involves partial cutting of the original forest vegetation [Bosque tropical subcaducifolio, Tropical Semideciduous Forest (Rzedowski 1978)] and cultivating coffee (Coffea arabica var. typica L.) under the shadow of the remaining trees. No fertilisers are used except decomposed coffee pulp. The productivity of these coffee plantations is relatively low, but the quality of coffee is high (Staver 1998).

Little is known about the soils of the region. A recent review (Alfaro Sánchez 2004) based mainly on the analysis of soil maps at a scale of 1:250 000 showed more the lack of data than a clear understanding of soils distribution in the region. A local study of soils of the area was published recently (García Calderón et al. 2000). According to the data reported, soils of the coffee-growing farms of the Sierra Sur of Oaxaca are mainly Acrisols, Luvisols, and Cambisols (FAO-ISRIC-ISSS 1998). Soils of the Finca Sinai farm were also partially described (Ibañez et al. 2001).

The total area of the farm is 365 ha. Twenty-two soil profiles were dug in the area, characterising the different landforms present at the site. Morphological description was done according to Cuanalo (1975). Samples for chemical analysis were collected from each soil horizon and analysed according to the routine methods of soil chemical and physical analyses.

In each sample we determined the texture using the hydrometer method (Tan 1996), pH with a glass-calomel electrode $\mathrm{pH}$ meter method (McLean 1982) $\left(\mathrm{H}_{2} \mathrm{O}\right.$ and $\mathrm{KCl} 1$ $\mathrm{N}$ extraction with a soil:solution ratio $1: 2.5)$, organic $\mathrm{C}$ by wet combustion (Nelson and Sommers 1982), exchangeable bases by the ammonium acetate method (Thomas 1982), and cation exchange capacity (CEC) as a sum of exchangeable bases and exchangeable acidity by the barium chloride-triethanolamine method (Tan 1996). The latter method was used instead of the traditional potassium chloride method (with separate determination of exchangeable $\mathrm{Al}$ and $\mathrm{H}$ ) because of the surprisingly low values of exchangeable acidity derived by $\mathrm{KCl}$ extraction, which were ascribed to specific potassium fixation in the soils studied (unpublished data).

Samples from four selected profiles were analysed for mineralogical composition. Clay fraction was separated and pre-treated using methods described in Kunze and Dixon (1986) and Dixon and White (1999). Fine silt (0.002-0.005 $\mathrm{mm}$ ) samples were separated from one of the profiles. X-ray difractograms were obtained on a diffractometer DRON-3 (SIE “Burevestnik", St. Petersburg, Russia, 1987), Cu-Ko radiation with graphite monochromer, $2 \theta 2-45^{\circ}, \mathrm{U}=40 \mathrm{kV}$, $\mathrm{I}=25 \mathrm{~mA}$.

The profiles were related to the landforms present at the study area. Unfortunately, no cartographic materials were available for the area, so we had to make our own topographic map using the data on coordinates (obtained by geopositioning system) and altitudes (obtained using an altimeter) of 420 points. The data were processed by SURFER software, Version 6.02 (Copyright $\left.^{(}\right)$1993-1996, Golden Software, Inc.).

\section{RESULTS}

\section{Soil Morphology and Classification}

The location of soil profiles in the area in relation to relief is shown in Fig. 2. In general, four soil groups cover the territory of the Finca Sinai farm.

\section{The First Group}

These soils are represented by clayey red-coloured profiles with an argic horizon. These soils occupy slopes crests and the upper parts of moderate slopes. Also, these soils form 


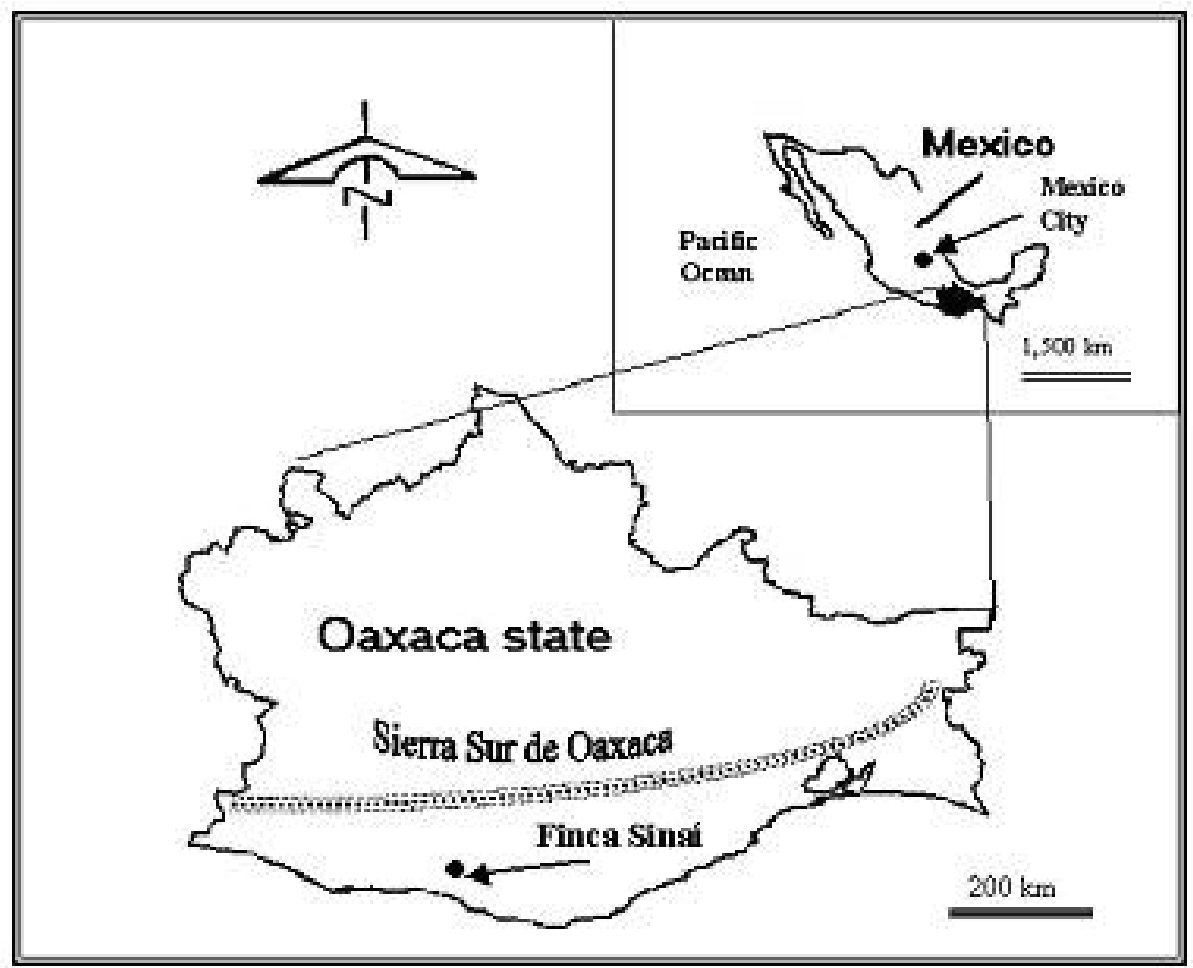

Fig. 1. The location of Finca Sinai coffee growing farm in the state of Oaxaca, Mexico.

residues of the old surfaces dissected by gullies. According to their morphology and diagnostic chemical properties, these soils were classified as Humic and Umbric Alisols (FAOISRIC-ISSS 1998). Morphology and chemical properties of these soils are represented by the profiles La Presa and El Ranchito in Tables 1 and 2. The thickness of humus-containing horizons ranges between 35 and $90 \mathrm{~cm}$ in Humic Alisols, and from 15 to $54 \mathrm{~cm}$ in Umbric Alisols. Some nonuniformity in colour was detected for epipedons of all the profiles listed. Distinct layers varying between 1 and $7 \mathrm{~cm}$ in thickness can be observed within epipedons of all the soils studied; some of these layers are lighter in colour than the rest of the A-horizon material, while other layers differ only in texture and gravel content. The texture tends to be heavier in argic horizon of the Alisol than their topsoil and parent material. The structure of all the soils studied is predominantly granular in the upper horizons, whereas argic horizons are characterised mostly by subangular blocky structure.

The maximum content of rock fragments in the Alisol is observed in the argic horizon, but most of these fragments are weathered to the state of soft saprolite. In La Presa profile, stones are concentrated mainly in the upper part of the argic horizon, forming a "stone line", which is believed to be an evidence of colluviation (Birkeland 1999).

\section{The Second Group}

These soils are also referred to Alisols (FAO-ISRIC-ISSS 1998). However, these soils are distinctly different in morphology from the soils of the first group, having loamy sand to sandy loam texture and yellowish brown colour of argic horizon (Figs. 1 and 2). They occupy moderate slopes. In the World Reference Base (FAO-ISRIC-ISSS 1998) these soils are classified as Arenic Alisols.

All the Alisol profiles have mica in both silt and sand fractions; lighter-textured soils have a greater number of mica flakes compared with clayey soils. Clay skins were identified on the ped surfaces in the argic horizon of Alisols. Biological activity is high in all the profiles, as earthworm and microarthropod activity was noticed during morphological description in the upper horizons. Roots are also abundant in the upper part of all the profiles, gradually decreasing with depth; few roots were found deeper than $1 \mathrm{~m}$.

\section{Soils of the Third and Fourth Groups}

These soils are brown and yellowish-brown, with loamy sand texture, without clay illuviation, and with an epipedon rich in organic matter. These soils are generally associated with gullies and steep slopes. Soils with thick humus layers generally occupy the uppermost and the lowest parts of the slopes. Soils with thinner humus layers appear to be related to steep slopes or gully-like valleys.

According to the World Reference Base (FAO-ISRICISSS 1998), these soils are divided into Mollic Cambisols and Arenic Umbrisols by the difference in base saturation in the epipedon. Data of three selected profiles are presented in Tables 1 and 2. Profile El Espinazo was classified as an Arenic Umbrisol, while profile El Portillo was classified as a Mollic Cambisol.

The thickness of the topsoil in Humic Arenic Umbrisols ranges between 55 and $76 \mathrm{~cm}$, whereas for Arenic Umbrisols 

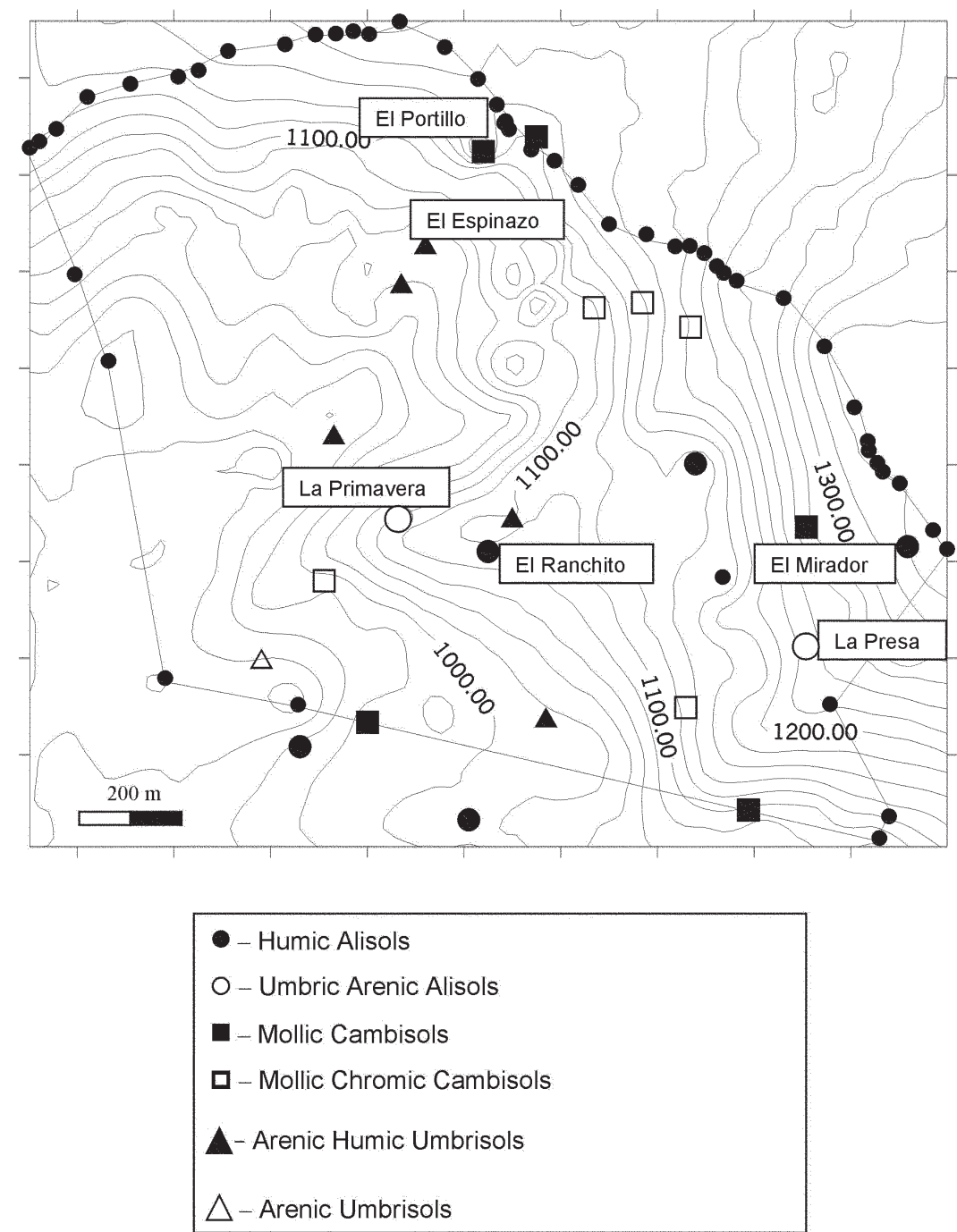

Fig. 2. Topographic map of Finca Sinai coffee growing farm. Elevation is in meters above sea level. The solid line marks the limits of the farm. The symbols represent locations and types of soils.

the range is $14-35 \mathrm{~cm}$. Mollic Cambisols have their surface horizon ranging between 26 and $75 \mathrm{~cm}$. Non-uniformity in colour was detected in all epipedons. The texture in various layers of epipedons varies from coarse-silty to sandy-skeletal.

In the Umbrisol, the textures of the subsoil are less heavy than in the upper horizons. The texture in Mollic Cambisols is uniform throughout the entire profile. The structure is mostly granular in the surface horizons, whereas cambic horizons are characterized by a mostly weak subangular blocky structure or are structureless. All Umbrisol are uniformly stony throughout the profile. In Cambisols, stone contents decrease with increasing depth. In general, Cambisol and Umbrisol profiles contain unweathered and slightly weathered micas in sand and silt fractions. In some cases, the distribution of mica was uniform throughout the profile, and occasionally it was higher in the $\mathrm{Bw}$ horizons.
Only a few clay skins along pores were detected in cambic horizons of the Umbrisol and Cambisol. Biological activity is high, and roots are abundant in humus-rich horizons of all profiles with gradual decrease with depth.

\section{Soil Chemical Properties}

The chemical properties of selected profiles are presented in Table 2. The umbric Epipedon of the Alisol (La Presa) has a high organic $\mathrm{C}$ content, high $\mathrm{CEC}$, and low base saturation. The acidity is high, with $\mathrm{pH}$ value $(1 \mathrm{M} \mathrm{KCl})$ as low as 3.8. The argic horizon is characterised by a relatively high organic matter content, relatively high CEC, and extremely low base saturation values. Among the exchangeable bases, $\mathrm{Ca}$ is the most abundant, and $\mathrm{Mg}$ and $\mathrm{K}$ are present in minor quantities, while $\mathrm{Na}$ content is low. The clay content of the Bt horizon increases almost three times compared with the $\mathrm{AB}$ horizon. 


\begin{tabular}{|c|c|c|c|c|c|c|c|c|}
\hline Profile & $\begin{array}{l}\text { Horizon, } \\
\text { depth }(\mathrm{cm})\end{array}$ & $\begin{array}{l}\text { Colour } \\
\text { (dry) }\end{array}$ & $\begin{array}{l}\text { Colour } \\
\text { (moist) }\end{array}$ & Field texture $^{\mathbf{Z}}$ & Structure $^{\mathbf{y}}$ & $\begin{array}{c}\text { Rock fragments, } \\
\text { volume } \%\end{array}$ & Clay films ${ }^{\mathbf{x}}$ & Rootsw \\
\hline $\begin{array}{l}\text { La Presa } \\
\text { (Umbric Alisol) } \\
\text { (First Group) }\end{array}$ & $\begin{array}{l}\text { A } 0-12 \\
\text { AB } 12-40 \\
\text { Bt1 } 40-90 \\
\text { Bt2 } 90-135\end{array}$ & $\begin{array}{l}10 \mathrm{YR} 4 / 3 \\
10 \mathrm{YR} 4 / 3 \\
5 \mathrm{YR} 5 / 6 \\
5 \mathrm{YR} 5 / 8\end{array}$ & $\begin{array}{l}10 \mathrm{YR} 2 / 2 \\
10 \mathrm{YR} 2 / 2 \\
2.5 \mathrm{YR} 4 / 6 \\
2.5 \mathrm{YR} 4 / 6\end{array}$ & $\begin{array}{l}\text { SL } \\
\text { SL } \\
\text { SCL } \\
\text { SCL }\end{array}$ & $\begin{array}{c}\text { gr } \\
\text { gr, sbk } \\
\text { sbk } \\
\text { sbk }\end{array}$ & $\begin{array}{c}0 \\
0 \\
<10 \\
10-30\end{array}$ & $\begin{array}{l}0 \\
0 \\
3 \\
2\end{array}$ & $\begin{array}{l}3 \\
2 \\
1 \\
0\end{array}$ \\
\hline $\begin{array}{l}\text { El Ranchito } \\
\text { (Humic Alisol) }\end{array}$ & $\begin{array}{ll}\text { A1 } & 0-12 \\
\text { A2 } & 12-31 \\
\text { AB } & 31-48 \\
\text { Bt1 } & 48-66 \\
\text { Bt2 } & 66-82 \\
\text { C1 } & 82-125 \\
\text { C2 } & 125-150\end{array}$ & $\begin{array}{l}\text { 7.5YR } 4 / 6 \\
7.5 \mathrm{YR} 4 / 3 \\
7.5 \mathrm{YR} 4 / 6 \\
7.5 \mathrm{YR} 5 / 6 \\
7.5 \mathrm{YR} 5 / 4 \\
7.5 \mathrm{YR} 6 / 6 \\
7.5 \mathrm{YR} 6 / 6\end{array}$ & $\begin{array}{l}5 \mathrm{YR} 3 / 4 \\
5 \mathrm{YR} 3 / 2 \\
5 \mathrm{YR} 3 / 4 \\
5 \mathrm{YR} 4 / 6 \\
5 \mathrm{YR} 4 / 6 \\
5 \mathrm{YR} 4 / 6 \\
5 \mathrm{YR} 4 / 6\end{array}$ & $\begin{array}{l}\text { CL } \\
\text { SCL } \\
\text { CL } \\
\text { CL } \\
\text { CL } \\
\text { SL } \\
\text { SL }\end{array}$ & $\begin{array}{l}\text { gr } \\
\mathrm{gr} \\
\mathrm{sbk} \\
\mathrm{sbk} \\
\mathrm{sbk} \\
\mathrm{sbk} \\
\mathrm{sbk}\end{array}$ & $\begin{array}{l}<10 \\
<10 \\
10-30 \\
10-30 \\
10-30 \\
30-50 \\
30-50\end{array}$ & $\begin{array}{l}0 \\
0 \\
1 \\
2 \\
2 \\
1 \\
0\end{array}$ & $\begin{array}{l}3 \\
3 \\
2 \\
1 \\
1 \\
1 \\
1\end{array}$ \\
\hline $\begin{array}{l}\text { El Mirador } \\
\text { (Arenic Alisol) } \\
\text { (Second Group) }\end{array}$ & $\begin{array}{l}\text { A1 } 0-39 \\
\text { A2 } 39-54 \\
\text { Bt } 54-76 \\
\text { BC } 76-128\end{array}$ & $\begin{array}{l}\text { 10YR3/3 } \\
10 Y R 4 / 3 \\
10 Y R 5 / 4 \\
10 Y R 5 / 4\end{array}$ & $\begin{array}{l}\text { 10YR2/1 } \\
10 \mathrm{YR} 2 / 2 \\
10 \mathrm{YR} 3 / 4 \\
10 \mathrm{YR} 4 / 4\end{array}$ & $\begin{array}{l}\text { SL } \\
\text { SL } \\
\text { SL } \\
\text { SL }\end{array}$ & $\begin{array}{c}\text { gr } \\
\text { gr } \\
\text { sbk } \\
\text { sbk }\end{array}$ & $\begin{array}{l}<10 \\
<10 \\
10-30 \\
10-30\end{array}$ & $\begin{array}{l}0 \\
0 \\
2 \\
1\end{array}$ & $\begin{array}{l}3 \\
2 \\
1 \\
1\end{array}$ \\
\hline $\begin{array}{l}\text { La Primavera } \\
\text { (Arenic Alisol) }\end{array}$ & $\begin{array}{l}\text { A1 } 0-21 \\
\text { A2 } 21-53 \\
\text { Bt } 53-75 \\
\text { C1 } 75-95 \\
\text { C2 } 295-142\end{array}$ & $\begin{array}{l}\text { 10YR4/3 } \\
10 \mathrm{YR} 4 / 3 \\
10 \mathrm{YR} 5 / 4 \\
10 \mathrm{YR} 5 / 4 \\
10 \mathrm{YR} 5 / 6\end{array}$ & $\begin{array}{l}10 \mathrm{YR} 3 / 2 \\
10 \mathrm{YR} 3 / 2 \\
10 \mathrm{YR} 3 / 3 \\
10 \mathrm{YR} 4 / 3 \\
10 \mathrm{YR} 4 / 4\end{array}$ & $\begin{array}{l}\text { SL } \\
\text { SL } \\
\text { SL } \\
\text { LS } \\
\text { LS }\end{array}$ & $\begin{array}{c}\mathrm{gr} \\
\mathrm{gr} \\
\mathrm{gr}, \mathrm{sbk} \\
\mathrm{sbk} \\
\mathrm{n}\end{array}$ & $\begin{array}{l}10-30 \\
10-30 \\
30-50 \\
>50 \\
>50\end{array}$ & $\begin{array}{l}0 \\
0 \\
2 \\
1 \\
0\end{array}$ & $\begin{array}{l}3 \\
3 \\
2 \\
1 \\
0\end{array}$ \\
\hline $\begin{array}{l}\text { El Espinazo } \\
\text { (Arenic Umbrisol) } \\
\text { (Third Group) }\end{array}$ & $\begin{array}{l}\text { A1 } 0-16 \\
\text { A2 } 16-36 \\
\text { Bw } 36-72 \\
\text { BC } 72-108 \\
\text { C } 108-172\end{array}$ & $\begin{array}{l}2.5 Y 5 / 3 \\
2.5 Y 5 / 3 \\
2.5 Y 7 / 4 \\
2.5 Y 7 / 4 \\
2.5 Y 7 / 4\end{array}$ & $\begin{array}{l}10 \mathrm{YR} 3 / 2 \\
10 \mathrm{YR} 3 / 3 \\
10 \mathrm{YR} 5 / 4 \\
10 \mathrm{YR} 5 / 4 \\
10 \mathrm{YR} 4 / 4\end{array}$ & $\begin{array}{l}\text { SL } \\
\text { SL } \\
\text { SL } \\
\text { LS } \\
\text { LS }\end{array}$ & $\begin{array}{c}\text { gr } \\
\text { gr } \\
\text { sbk } \\
\text { gr } \\
\mathrm{n}\end{array}$ & $\begin{array}{c}30-50 \\
<10 \\
0 \\
0 \\
0\end{array}$ & $\begin{array}{l}0 \\
0 \\
1 \\
0 \\
0\end{array}$ & $\begin{array}{l}3 \\
2 \\
1 \\
1 \\
1\end{array}$ \\
\hline $\begin{array}{l}\text { El Portillo } \\
\text { (Mollic Cambisol) } \\
\text { (Fourth Group) }\end{array}$ & $\begin{array}{l}\text { A } 0-28 \\
\text { Bw 28-58 } \\
\text { BC 58-103 } \\
\text { C 103-147 }\end{array}$ & $\begin{array}{l}10 \mathrm{YR} 5 / 3 \\
10 \mathrm{YR} 5 / 3 \\
10 \mathrm{YR} 6 / 4 \\
10 \mathrm{YR} 6 / 4\end{array}$ & $\begin{array}{l}10 \mathrm{YR} 3 / 3 \\
10 \mathrm{YR} 4 / 4 \\
10 \mathrm{YR} 4 / 6 \\
10 \mathrm{YR} 4 / 4\end{array}$ & $\begin{array}{l}\text { SL } \\
\text { LS } \\
\text { LS } \\
\text { LS }\end{array}$ & $\begin{array}{c}\text { gr } \\
\text { gr, sbk } \\
\text { gr, sbk } \\
\text { n }\end{array}$ & $\begin{array}{r}0 \\
0 \\
<10 \\
0\end{array}$ & $\begin{array}{l}0 \\
0 \\
0 \\
0\end{array}$ & $\begin{array}{l}3 \\
2 \\
2 \\
1\end{array}$ \\
\hline
\end{tabular}

${ }^{\mathrm{z} L S}$, loamy sand; SL, sandy loam; SCL, sandy clay loam; CL, clay loam.

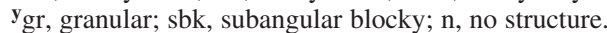

${ }^{x_{0}}$, no clay films; 1 , few; 2 , common; 3 , many.

${ }^{\mathrm{w}} 0$, no roots; 1 , few; 2 , common; 3 , many.

The epipedons of the Humic Alisols (El Ranchito) are relatively rich in organic $\mathrm{C}$. They have a high base saturation; therefore, they fulfil colour and structure criteria for a mollic epipedon. Organic $\mathrm{C}$ content is about $10 \mathrm{~g} \mathrm{~kg}^{-1}$ in the transitional $\mathrm{AB}$ horizon and in the upper part of the argic horizon, down to $66 \mathrm{~cm}$. Organic $\mathrm{C}$ of the upper soil horizons in other profiles of the Humic Alisols varies between 22 and $56 \mathrm{~g} \mathrm{~kg}^{-1}$. Base saturation in argic horizons is still much higher than in La Presa profile. The difference in clay content between the epipedons and $\mathrm{Bt}$ horizons is also smaller than in the La Presa soils. The A2 horizon has significantly lower clay content than the overlaying $\mathrm{A} 1$ and $\mathrm{AB}$ horizons. Calcium is the dominant cation and this is followed by $\mathrm{Mg}$, and $\mathrm{Na}$, while $\mathrm{K}$ is present in minor amount.

The epipedon of the El Mirador soil (Arenic Alisol) has low $\mathrm{pH}$ values and has low base saturation. Organic $\mathrm{C}$ content is high in the upper part of the epipedon, but decreases with depth. The organic $\mathrm{C}$ content in the argic horizon is low. Clay content increases in the Bt horizon compared with the surface soil. The sequence of exchangeable cations in the profile is, generally, as follows: $\mathrm{Ca}>\mathrm{Mg}$
$>\mathrm{K}>\mathrm{Na}$. However, $\mathrm{K}$ content in A2 horizon is higher than that of $\mathrm{Mg}$.

The surface horizon of the La Primavera soil (Arenic Alisol) is also rich in organic matter. The A1 horizon has a moderate base saturation (slightly more than 50\%), and the A2 horizon is unsaturated. Saturation is also low in the Bt horizon and in the $\mathrm{C} 1$ and $\mathrm{C} 2$ horizons. The soil has sandy to loamy sand texture, with an increase in clay content in the Bt horizon from 76 to $116 \mathrm{~g} \mathrm{~kg}^{-1}$ (an increase of more than $3 \%$ required for an argic horizon). The sequence of exchangeable bases is: $\mathrm{Ca}>\mathrm{Mg}>\mathrm{Na}>\mathrm{K}$. In the lower part of the epipedon the content of $\mathrm{Na}$ is higher than that of $\mathrm{Mg}$.

In the El Espinazo soil (Arenic Umbrisol) the surface soil has a lower organic $\mathrm{C}$ content compared with the Alisols. In other soils of this group C content varies between 32 and $42 \mathrm{~g} \mathrm{~kg}^{-1}$ in the Humic Arenic Umbrisols and between 15 and $41 \mathrm{~g} \mathrm{~kg}^{-1}$ in the Arenic Umbrisols. Base saturation values are in the range of 30-37\% in the epipedon as well as in the cambic horizon and parent material. Clay content does not change with depth. The sequence of exchangeable bases in the upper horizons is $\mathrm{Ca}>$ $\mathrm{K}>\mathrm{Mg}>\mathrm{Na}$, and $\mathrm{K}>\mathrm{Ca}>\mathrm{Na}>\mathrm{Mg}$ in the lower ones. 


\begin{tabular}{|c|c|c|c|c|c|c|c|c|c|c|c|c|c|}
\hline Profile & $\begin{array}{c}\text { Horizon, } \\
\text { depth }(\mathrm{cm})\end{array}$ & $\mathrm{pHH}_{2} \mathrm{O}$ & $\mathrm{pHKCl}$ & $\begin{array}{c}\text { Clay } \\
\left(\mathrm{g} \mathrm{kg}^{-1}\right)\end{array}$ & $\mathrm{Ca}^{2+}$ & $\mathrm{Mg}^{2+}$ & $\mathrm{K}^{+}$ & $\mathrm{Na}^{+}$ & $\mathrm{EA}^{\mathrm{z}}$ & CEC & $\begin{array}{c}\text { CEC } \\
\text { per kg clay }\end{array}$ & $\begin{array}{l}\mathrm{BS} \\
(\%)\end{array}$ & $\begin{array}{c}\mathrm{C} \\
\left(\mathrm{g} \mathrm{kg}^{-1}\right)\end{array}$ \\
\hline La Presa & A $0-12$ & 5.2 & 3.8 & 80 & 64.2 & 8.3 & 5.1 & $\begin{array}{c}\mathrm{nmol} \mathrm{kg} \\
1.1\end{array}$ & 188.7 & 267.3 & 3340 & 29.4 & 55.5 \\
\hline (Umbric & $\mathrm{AB} 12-40$ & 5.2 & 3.8 & 112 & 39.6 & 4.5 & 4.4 & 1.1 & 185.8 & 235.4 & 2100 & 21.1 & 51.6 \\
\hline Alisol) & Bt1 40-90 & 5.3 & 3.9 & 308 & 3.6 & 0.7 & 1.6 & 1.1 & 95.1 & 102.2 & 330 & 6.9 & 17.3 \\
\hline (First Group) & Bt2 90-135 & 5.4 & 3.9 & 252 & 5.5 & 0.9 & 1.4 & 0.8 & 100.3 & 108.8 & 430 & 7.8 & 5.0 \\
\hline El Ranchito & A1 0-12 & 5.4 & 5.0 & 316 & 71.6 & 35.8 & 3.0 & 17.1 & 87.0 & 214.5 & 680 & 59.4 & 22.0 \\
\hline \multirow[t]{6}{*}{ (Humic Alisol) } & A2 $12-31$ & 5.5 & 5.2 & 240 & 71.6 & 35.8 & 3.0 & 7.6 & 114.2 & 232.2 & 970 & 50.8 & 28.7 \\
\hline & AB $31-48$ & 5.5 & 4.8 & 336 & 40.3 & 24.6 & 2.6 & 3.3 & 93.9 & 164.7 & 490 & 43.0 & 10.0 \\
\hline & Bt1 48-66 & 5.5 & 4.6 & 376 & 35.8 & 22.4 & 3.0 & 8.7 & 99.5 & 169.4 & 450 & 41.3 & 10.0 \\
\hline & Bt2 66-82 & 5.6 & 4.7 & 356 & 35.8 & 22.4 & 2.6 & 13.8 & 106.4 & 181.0 & 510 & 41.2 & 6.3 \\
\hline & C1 82-125 & 5.5 & 4.7 & 176 & 11.2 & 17.9 & 2.6 & 13.8 & 76.6 & 122.1 & 690 & 37.3 & 2.7 \\
\hline & C2 125-150 & 5.9 & 4.6 & 176 & 11.2 & 11.2 & 2.6 & 14.1 & $\mathrm{ND}^{\mathrm{y}}$ & ND & ND & ND & 2.7 \\
\hline El Mirador & A1 $0-39$ & 5.5 & 4.0 & 92 & 59.1 & 6.8 & 5.1 & 0.8 & 190.3 & 262.1 & 2850 & 27.4 & 28.5 \\
\hline (Arenic Alisol) & A2 39-54 & 5.3 & 4.1 & 92 & 10.2 & 0.7 & 3.6 & 0.8 & 160.4 & 175.7 & 1910 & 8.7 & 10.8 \\
\hline \multirow{2}{*}{$\begin{array}{l}\text { (Second } \\
\text { Group) }\end{array}$} & Bt 54-76 & 5.2 & 4.0 & 152 & 20.8 & 2.1 & 1.6 & 0.8 & 125.9 & 151.1 & 990 & 16.7 & 3.0 \\
\hline & BC 76-128 & 5.5 & 4.0 & 112 & 21.3 & 2.2 & 1.8 & 1.1 & 103.8 & 130.2 & 1160 & 20.3 & 2.2 \\
\hline La Primavera & A1 $0-21$ & 5.3 & 4.7 & 76 & 103.0 & 33.6 & 2.1 & 20.0 & 146.8 & 305.5 & 4020 & 51.9 & 31.8 \\
\hline \multirow[t]{4}{*}{ (Arenic Alisol) } & A2 21-53 & 5.3 & 4.7 & 76 & 56.0 & 15.6 & 2.3 & 17.1 & 128.3 & 219.3 & 2890 & 41.5 & 22.7 \\
\hline & Bt $53-75$ & 5.2 & 4.2 & 116 & 31.3 & 11.2 & 2.3 & 8.4 & 98.5 & 151.7 & 1310 & 35.1 & 13.1 \\
\hline & C1 75-95 & 5.4 & 4.2 & 56 & 13.4 & 2.2 & 1.7 & 5.1 & 83.3 & 105.7 & 1890 & 21.2 & 3.8 \\
\hline & C2 95-142 & 5.5 & 4.3 & 56 & 15.6 & 8.9 & 2.1 & 6.4 & 57.5 & 90.5 & 1620 & 36.5 & 2.8 \\
\hline El Espinazo & A1 0-16 & 6.5 & 5.3 & 84 & 35.0 & 8.2 & 9.5 & 6.1 & 119.5 & 178.3 & 2120 & 33.0 & 15.2 \\
\hline (Arenic & A2 16-36 & 6.5 & 5.3 & 64 & 22.3 & 4.7 & 9.5 & 5.1 & 92.3 & 133.9 & 2090 & 31.1 & 10.1 \\
\hline Umbrisol) & Bw 36-72 & 6.3 & 5.5 & 64 & 13.0 & 3.5 & 9.5 & 5.1 & 58.7 & 89.8 & 1400 & 34.6 & 1.4 \\
\hline \multirow[t]{2}{*}{ (Third Group) } & BC 72-108 & 6.2 & 5.3 & 44 & 7.1 & 1.1 & 10.4 & 5.0 & 46.3 & 69.9 & 1590 & 33.8 & 1.1 \\
\hline & C $108-172$ & 6.3 & 5.8 & 44 & 5.9 & 2.3 & 10.4 & 5.1 & 39.7 & 63.4 & 1440 & 37.4 & 0.3 \\
\hline El Portillo & A $0-28$ & 5.7 & 4.7 & 52 & 111.2 & 9.4 & 7.3 & 1.9 & 96.6 & 226.4 & 4350 & 57.3 & 24.1 \\
\hline (Mollic & Bw 28-58 & 5.5 & 4.6 & 52 & 105.4 & 9.5 & 2.8 & 1.1 & 67.7 & 186.6 & 3590 & 63.7 & 7.4 \\
\hline Cambisol) & BC 58-103 & 5.7 & 4.3 & 52 & 66.0 & 8.4 & 4.0 & 4.0 & 102.9 & 185.4 & 3560 & 44.5 & 2.0 \\
\hline (Forth Group) & C $103-147$ & 5.7 & 4.2 & 32 & 81.1 & 10.1 & 4.9 & 0.8 & 84.7 & 181.6 & 5680 & 53.4 & 2.0 \\
\hline
\end{tabular}

${ }^{\mathbf{z} E A}$, exchangeable acidity $\left[\mathrm{BaCl}_{2}-\right.$ triethanolamine method (Tan 1996)]

$\mathrm{y}_{\mathrm{ND}}$, not determined.

As for the Mollic Cambisols, they have a relatively high organic $\mathrm{C}$ content and high base saturation $(>50 \%)$ in all the horizons except in the transitional BC. Clay content is uniform throughout the profile. The sequence of exchangeable bases is $\mathrm{Ca}>\mathrm{Mg}>\mathrm{K}>\mathrm{Na}$.

\section{Soil Mineralogy}

The mineralogical composition of the clay fraction from the La Presa soil (Humic Alisol) is shown in Fig. 3. The upper two horizons have similar mineralogical composition. The main components are kaolinite (basal signals at 0.72 and $0.365 \mathrm{~nm}$ ) and gibbsite (peak at $0.482 \mathrm{~nm}$ ). The kaolin group is represented by both kaolinite and dehydrated halloysite, which is detected by an intensive non-basal signal at $0.444 \mathrm{~nm}$ (Dixon 1989). The 2:1 minerals are represented by a mixed-layered mica-vermiculite, which shows a peak of $1.13 \mathrm{~nm}$ when airdried, and 1.01 after heating. A weak signal at $2.2-2.3 \mathrm{~nm}$ in the XRD pattern of a sample from the A horizon hints at the presence of a well-ordered interlayering. The content of micavermiculite is slightly higher in the $\mathrm{AB}$ than in the A horizon. Bt horizons are distinctly different from the topsoil, as they virtually lack 2:1 minerals except for a small peak at $1.01 \mathrm{~nm}$ in the Bt1 horizon after heating. No other evidence of such minerals was observed in the XRD.

We also studied the mineralogical composition of the fine silt fraction from the La Presa soil (Fig. 4). The CEC of the fine earth of the soils studied was exceptionally high for the kaolinite-gibbsite association. We hypothesised that the silt fraction could contribute to the exchange capacity of these soils. The fine silt of the upper two horizons had an almost identical composition to that of the clay fraction; slightly larger d-spacing of mica-vermiculite showed a greater proportion of vermiculite in 2:1 mineral mixtures in the fine silt fraction. In the Bt horizons of the soils, the silt fraction has a significant amount of $1.19 \mathrm{~nm}$ mica-vermiculite mineral, which is absent in the clay fraction of these horizons.

XRD patterns for the clay fractions obtained from the horizons of the El Mirador soil (Arenic Alisol) are shown in Fig. 5. All horizons of the profile are dominated by kaolin minerals and gibbsite. A significant part of the kaolin minerals is dehydrated halloysite. The 2:1 minerals are represented by a $1.13 \mathrm{~nm}$ mixed-layered mica-vermiculite. The mineralogical composition of the clay fraction is uniform in 
A 0-12 (Mg-saturated, air-dried)

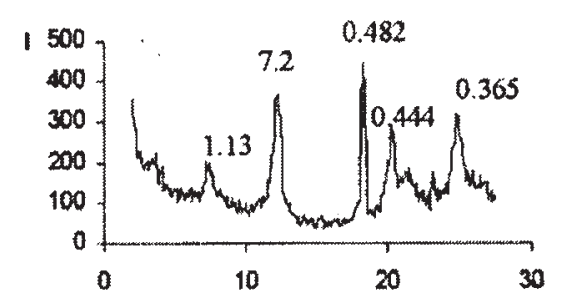

AB 12-40

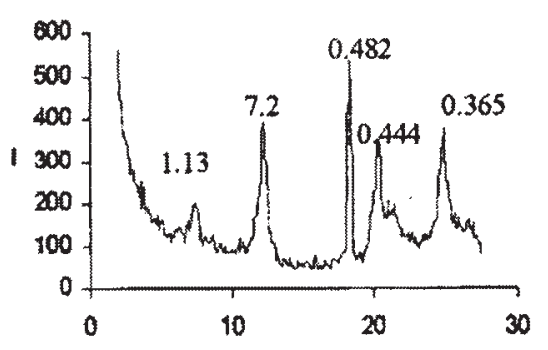

Bt1 40-90

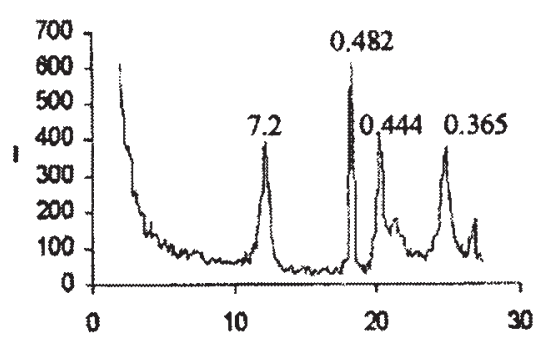

B12 90-135

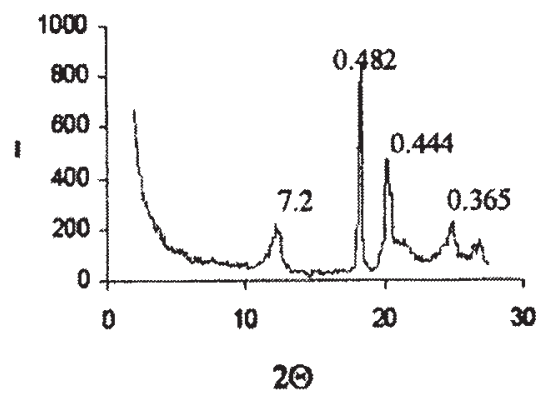

A 0-12 (Mg-saturated, $550^{\circ} \mathrm{C}$ )

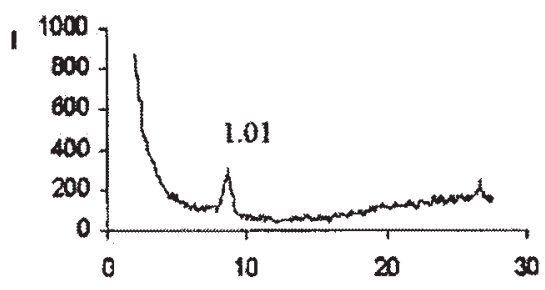

AB 12-40

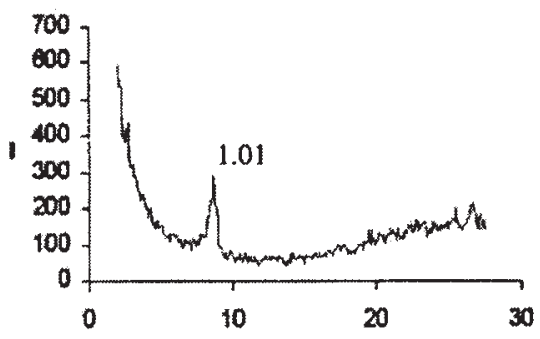

Bt1 40-90

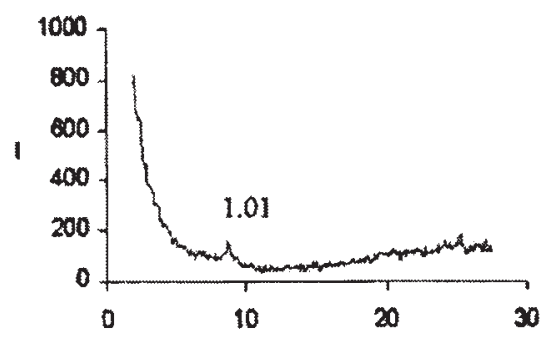

Bt2 90-135

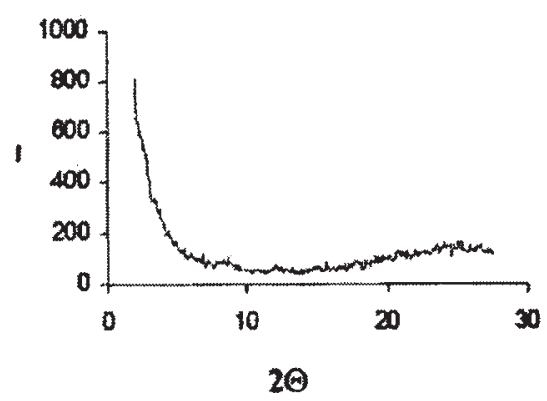

Fig. 3. X-ray difractograms for oriented samples of clays obtained from the horizons of the profile of an Umbric Alisol (La Presa).

this profile, apart from a slightly lower gibbsite content in the A1 horizon.

The mineralogical composition of the clay fraction from the genetic horizons of the La Primavera soil (Arenic Alisol) is shown in Fig. 6. In all horizons the dominant minerals were of the kaolin group. The presence of dehydrated halloysite minerals can be suspected, due to some asymmetry in the 0.72 $\mathrm{nm}$ peak, and to a relatively good peak at $0.444 \mathrm{~nm}$, typical 
A 0-12 (Mg-saturated, air-dried)

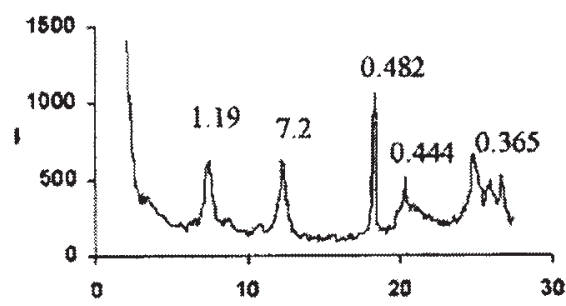

AB $12-40$

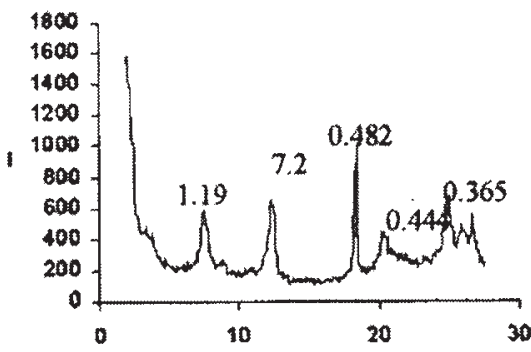

Bt1 40-75

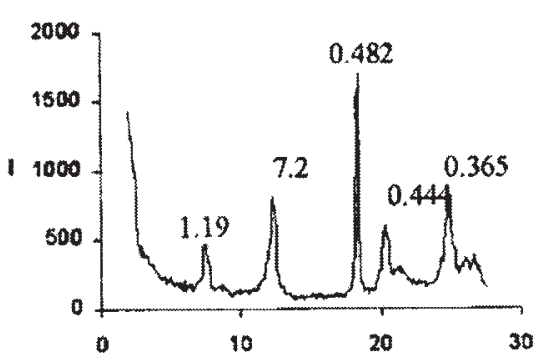

$B+275-135$

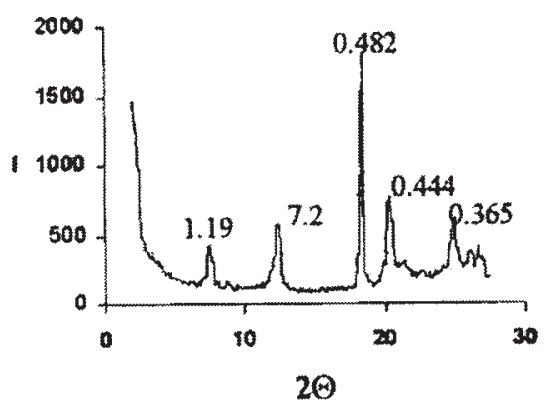

\section{A Q-12 (Mg-saturated, $\left.550^{\circ} \mathrm{C}\right)$}

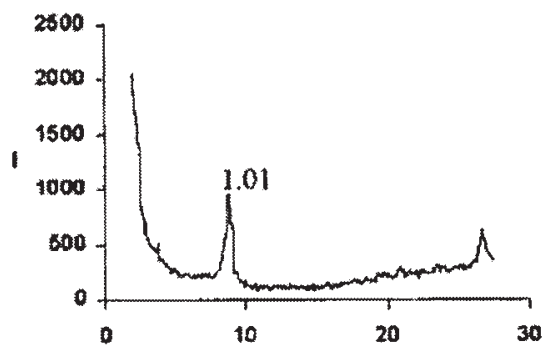

AB 12-40

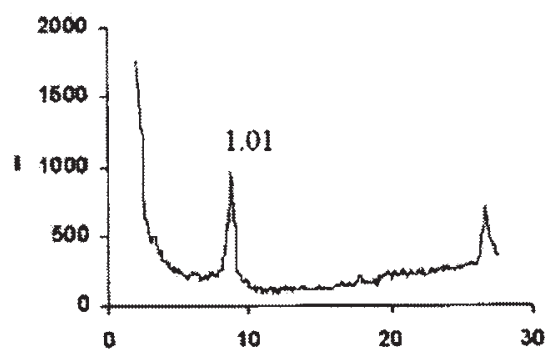

Bt1 40-75

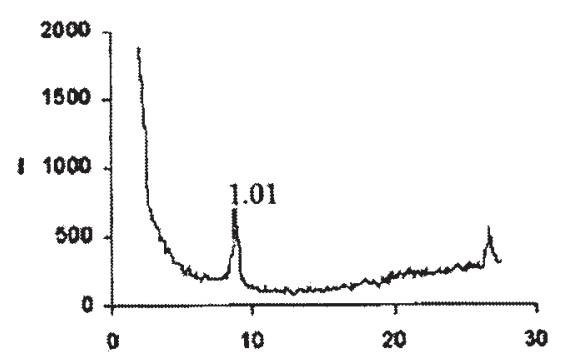

Bt2 75-135

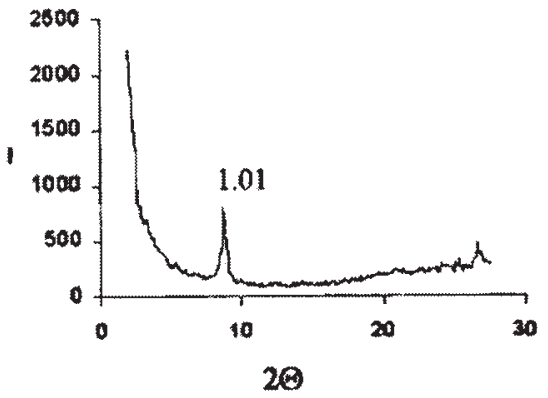

Fig. 4. X-ray difractograms for oriented samples of fine silt $(0.002-0.005 \mathrm{~mm})$ obtained from the horizons of the profile of an Umbric Alisol (La Presa).

for halloysite. However, kaolinite is the dominant mineral in the soil. The gibbsite content varies through the profile. It is less in the lower part of the surface horizon than in the surface one, and is gradually extending in the cambic and $\mathrm{C} 1$ horizons, and then decreases in the lower part of the parent material (C2). The 2:1 minerals give a series of minor signals of 
A1 0-39 ( $\mathrm{Mg}$-s aturated, air-dried)

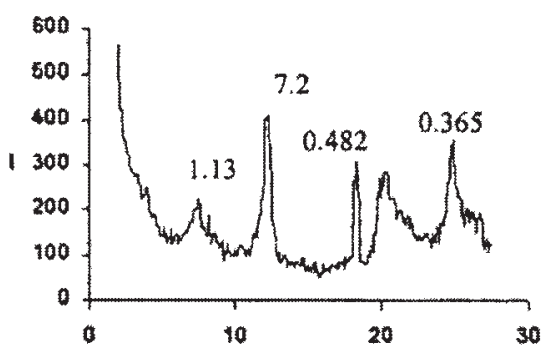

A2 39.54

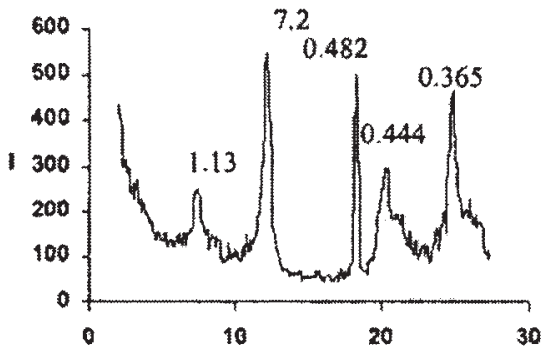

Bt $\mathbf{5 4 - 7 6}$

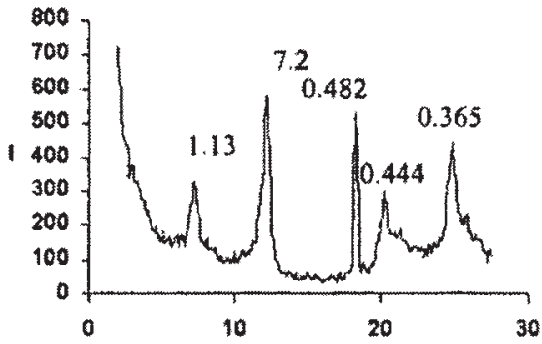

BC 76-128

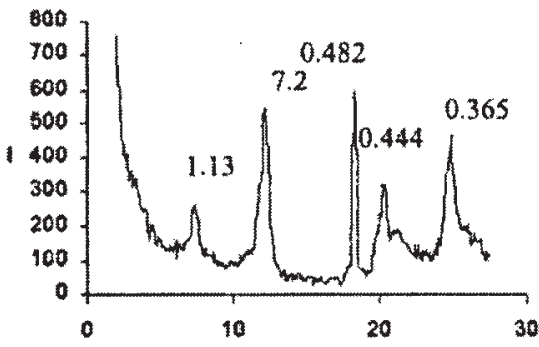

$2 \Theta$
A1 0-39 (ing-saturated, $550 \mathrm{C})$

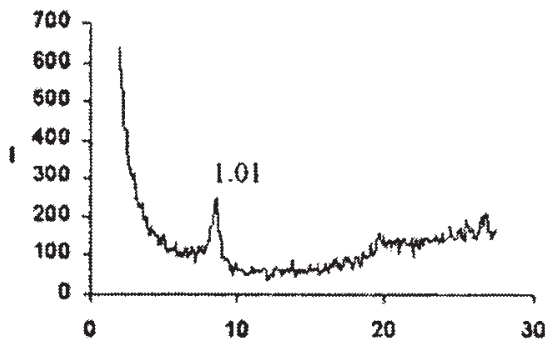

A2 39-54

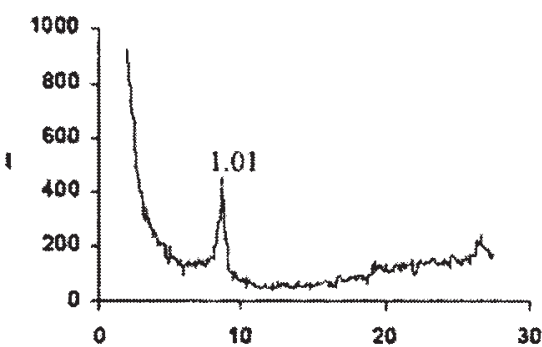

Bt $\mathbf{5 4 . 7 6}$

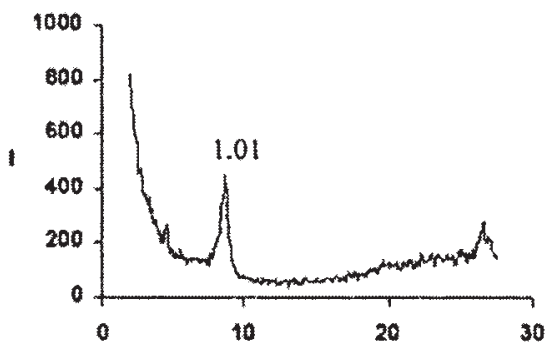

BC 76-128

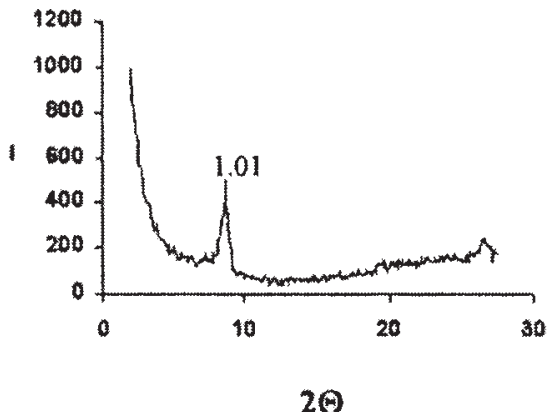

Fig. 5. X-ray difractograms for oriented samples of clays obtained from the horizons of the profile of an Arenic Alisol (El Mirador).

$1.01,1.13$, and $1.26 \mathrm{~nm}$. Their behaviour after heating differs with different horizons. Total collapse of crystal structures to $1.01 \mathrm{~nm}$ is detected in horizons A2 and C1.
Minerals were mica (1.01 $\mathrm{nm}$ in the air-dried sample) and interstratified mica-vermiculites (1.13 and $1.26 \mathrm{~nm}$ ). The low intensity of these signals and the absence of second and third 
A1 0.21 (A g-saturated, air-dry)

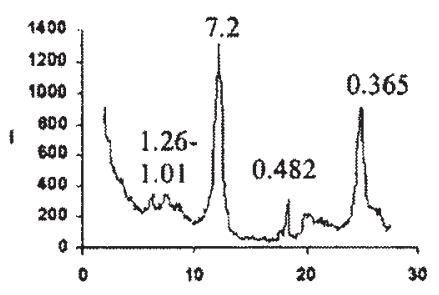

A2 $21-53$

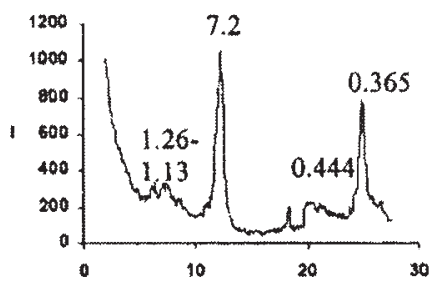

Bt: $\mathbf{3 3 . 7 5}$

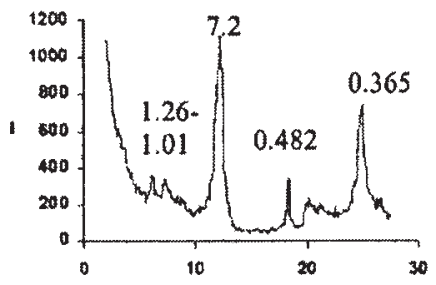

c. $75-95$

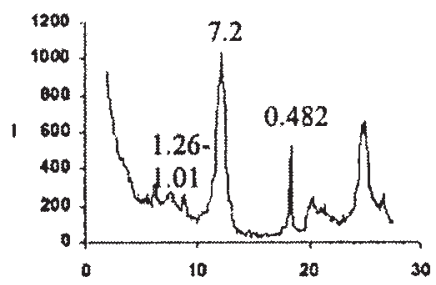

C2 $95-142$

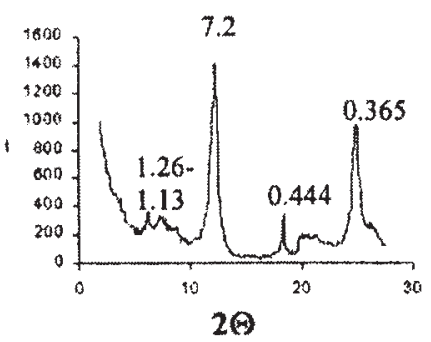

A1 0.21 ding-saturatod, $350 \mathrm{C}$

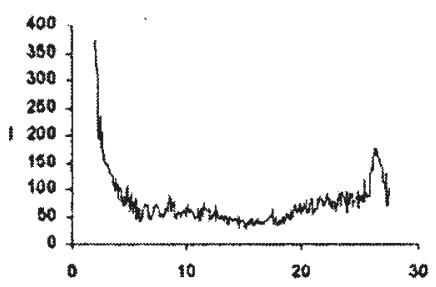

A2 21.53

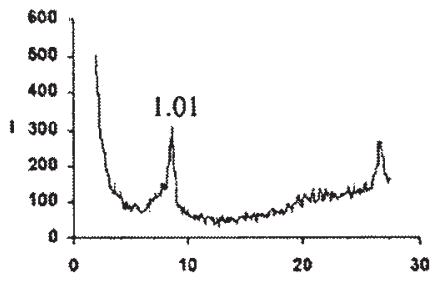

Bt 53.75

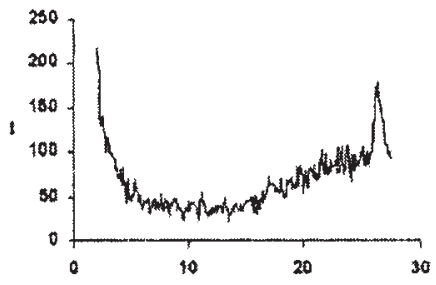

c175.95

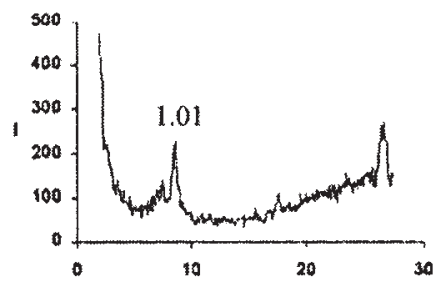

C2 $85-142$

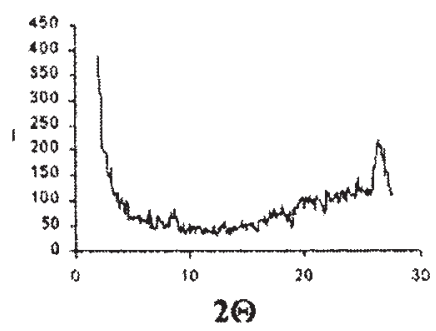

Fig. 6. X-ray difractograms for oriented samples of clays obtained from the horizons of the profile of an Arenic Alisol (La Primavera).

order basal peaks do not allow suggestions on the crystal structure of these minerals. The asymmetry of the $1.01 \mathrm{~nm}$ peak after heating in the sample from the $\mathrm{A} 2$ horizon and the presence of a small $1.10 \mathrm{~nm}$ peak in the $\mathrm{C} 1$ horizon indicate that mica-vermiculite in these horizons may contain interlayer aluminium. Signals of 2:1 minerals disappear almost 
A 0-28 (Mg-saturated, air-dry)

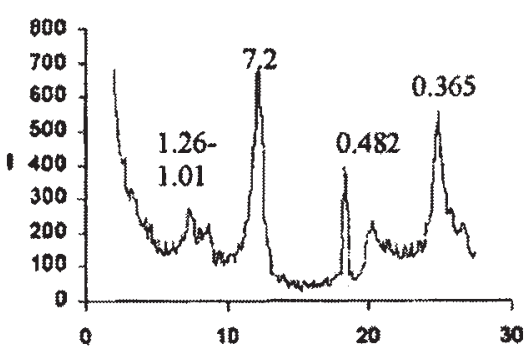

AB 28-58

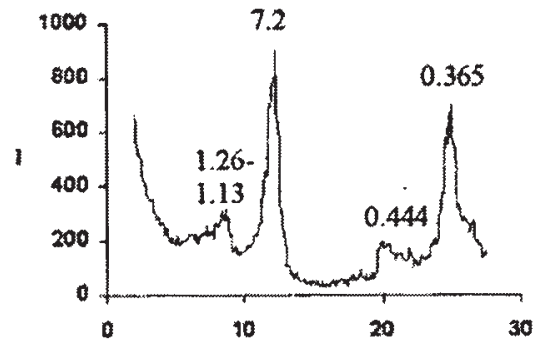

Bw 58-103

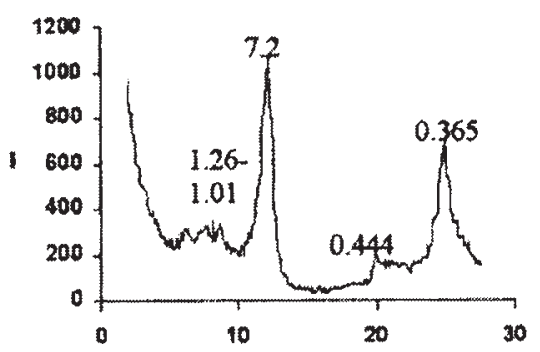

BC 103-147

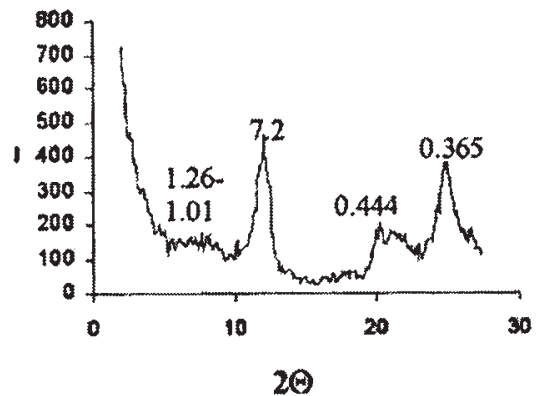

A 0-28 (Mg-saturated, $\left.550^{\circ} \mathrm{C}\right)$

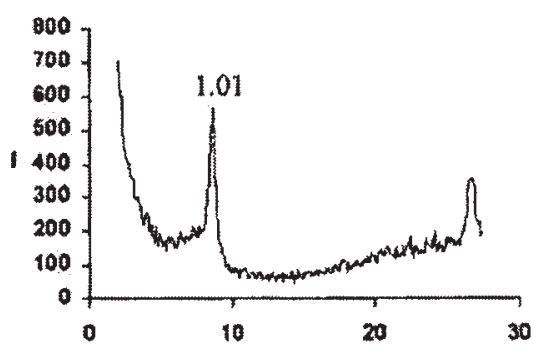

AB 28-58

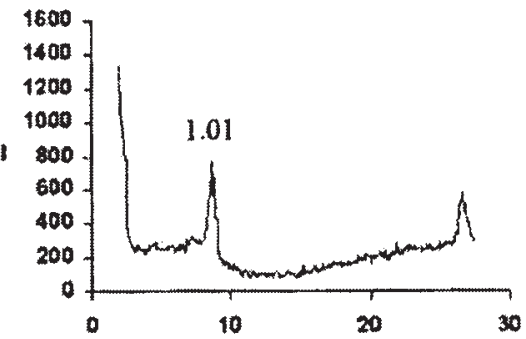

Bw 58-103

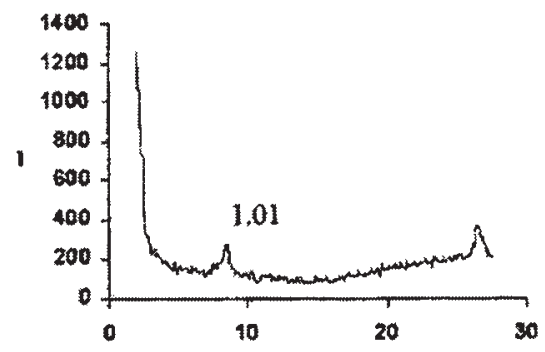

BC 103-147

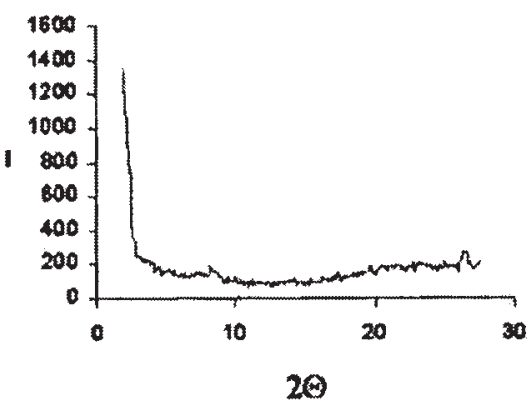

Fig. 7. X-ray difractograms for oriented samples of clays obtained from the horizons of the profile of an Mollic Cambisol (El Portillo).

entirely in the other three horizons (A1, Bw, and $\mathrm{C} 2)$. This can be attributed to their smaller size and poorer crystallinity; heating could cause disorientation of clay mineral particles.
Difractograms for clay fractions of the El Portillo profile (Mollic Cambisol) are depicted in Fig. 7. The dominant mineral group is kaolin. All the difractograms also have 

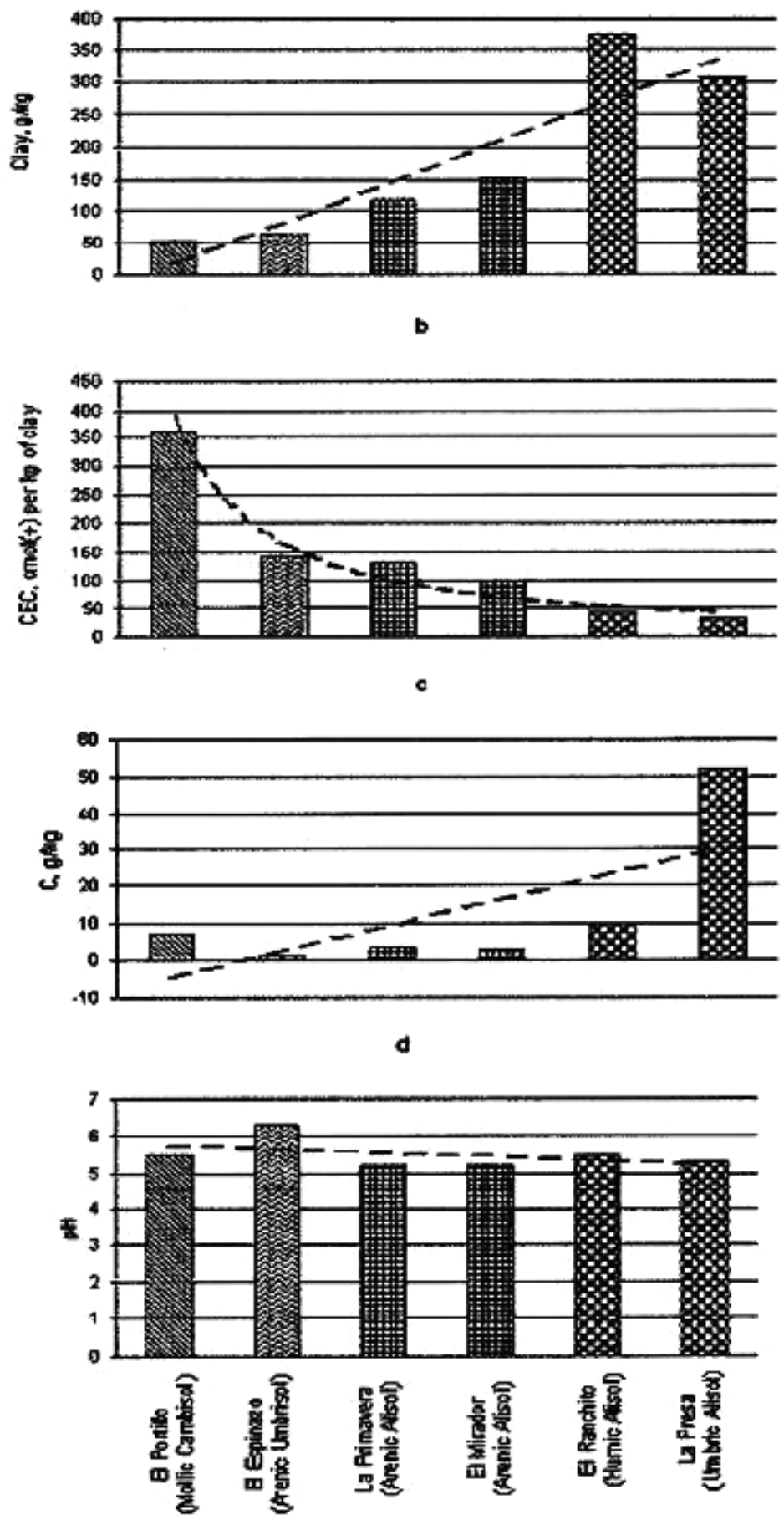

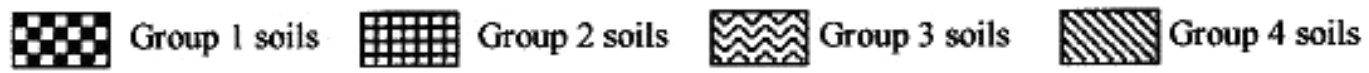

Fig. 8. Properties of $\mathrm{Bt}(\mathrm{Bw})$ horizons of soils studied arranged according to the proposed evolutionary scheme. $\mathrm{a}-\mathrm{clay}$ content, $\mathrm{b}-\mathrm{cation}$ exchange capacity per kg of clay, $\mathrm{c}$ - organic $\mathrm{C}$ content, $\mathrm{d}-\mathrm{pH}\left(\mathrm{H}_{2} \mathrm{O}\right)$ values. Dotted lines show trends in soil development.

non-basal signals at $0.444 \mathrm{~nm}$, pointing at the presence of dehydrated halloysite. Only the A horizon has evidence of having a significant amount of gibbsite. The 2:1 minerals are represented by mica $(1.01 \mathrm{~nm})$ and mixed-layered mica- 


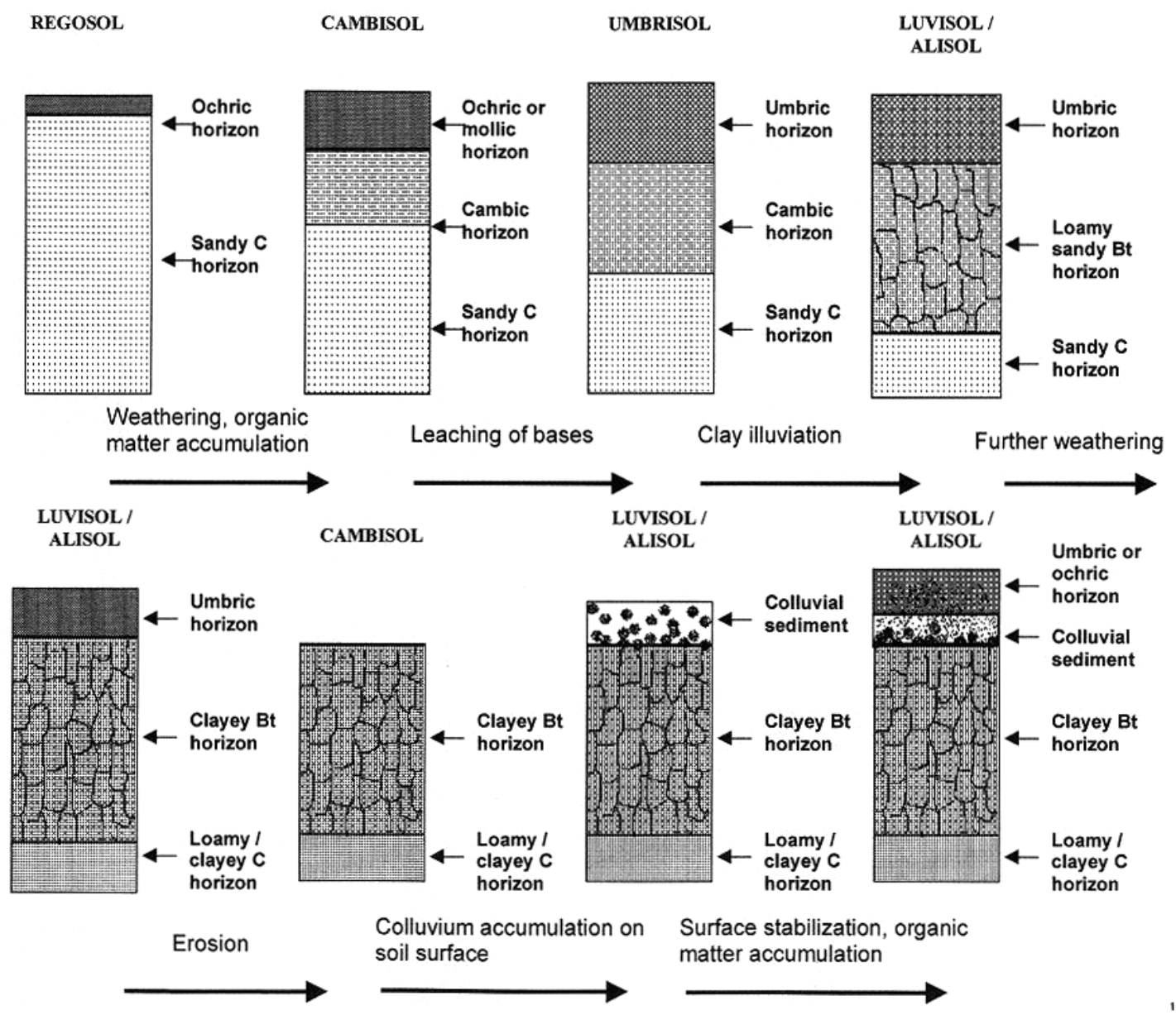

Fig. 9. Proposed model for soil development in Sierra Sur de Oaxaca.

vermiculite $(1.26 \mathrm{~nm})$. Both 2:1 minerals are present in the A horizon. Only the $1.01 \mathrm{~nm}$ peak is detected in the cambic Bw horizon, but with a significant asymmetry towards to lower angles. Almost none of the 2:1 minerals are present in the subsoil.

\section{DISCUSSION}

\section{Soil Properties}

The soils of the first group (Humic and Umbric Alisols) were considered to be the most developed ones in the study area. Alisols are generally formed through the process of strong weathering and leaching. The weathering is evidenced by a kaolinite-gibbsite mineral association in the clay fraction of the Bt horizons in the studied profile (Fig. 3). These minerals are believed to be the final stages of a soil mineral weathering sequence (Dixon 1989). Kaolinite could form directly from biotite weathering, as it has been observed in sand-sized biotite grains in similar tropical soils (Kretzschmar et al. 1997). Also, it could be a product of halloysite dehydration that originates from feldspars or biotite weathering under a wide range of pedoenvironments (Singer et al. 2004). The presence of gibbsite, which has not been reported for the study area before (García Calderon 2000), may be due to the high aluminum content of the bedrock. The presence of anorthosite rich in aluminum can be an explanation for the presence of gibbsite in even less weathered soils of the second group.

Although clayey Alisols have the appearance of highly weathered substrates usually associated with low-activity clays, the CEC values per kilogram of clay are surprisingly high. The phenomenon may be explained by a high content of active minerals (mica-vermiculites) in the silt fraction as demonstrated by XRD data for the La Presa soil (Fig. 4). It is similar to data of other researchers who showed that illite can be rather stable in coarse fractions of tropical soils in comparison with feldspars (Rutherford 1987). Both soil morphology (Table 1) and texture data (Table 2) indicate clay illuviation in the Bt horizon. Recent studies (Drees et al. 2003) show that soils with an argic horizon can form on extremely steep slopes; our unpublished results of the field studies in the mountains of Mexico also confirm the abundance of soils with clay-illuviation in steeplands.

The soils of the second group show morphological and chemical properties and mineralogical composition of clay fraction similar to the soils of the first group. However, several important differences exist. The soil texture is coarser; their colour is less red; in the clay fraction together with 
kaolinite and gibbsite there are halloysite and mixed-layered mica-vermiculite. An asymmetric peak at $1.01 \mathrm{~nm}$ after heating indicates the presence of Al-interlayered 2:1 minerals, a common feature for illuvial horizons of temperate forest soils (Pai et al. 2004). The complex of these properties indicates that the soils are less weathered than the soils of the first group. Both morphology and texture indicate less clay illuviation in the profiles of the second group than in the soil of the first group. In general, we can consider Arenic Alisols as less developed, than Umbric or Humic Alisols due to the difference in soil age or in the intensity of pedogenesis. The latter hypothesis is not very strong, since all the studied profiles develop under the same climate and vegetation. Also, we found no strict correspondence of soils of the two groups to slope angle or aspect, which usually affect pedogenesis in the mountains. Thus, we considered the difference in time of soil development as the most probable explanation of the existing differences between the two groups of soils.

The soils of the third group are similar in texture and most chemical properties (e.g., base saturation and clay activity) to the soils of the second group, but have neither morphological nor analytical evidence of clay illuviation. The same is true for the soils of the fourth group, which also have higher base saturation indicating even less leaching of the profile. However, clay mineralogy of these soils is still characterised by the dominance of kaolin minerals. The difference in clay mineralogy from the soils of the first and second groups is mainly a higher proportion of halloysite and 2:1 minerals. An important feature of the profile distribution of 2:1 minerals in the clay fraction of a Mollic Cambisol (El Portillo) is that clay fractions of the upper horizons of the profile have a higher proportion of illite than of disordered mixed-layered illite-vermiculite. The phenomenon might be ascribed to fresh colluvial material accumulation on the surface or to potassium fixation in illite-vermiculite (Ghabru et al. 1987), which causes its regradation to illite in the surface horizons. The latter hypothesis is supported by chemical data, showing relatively high exchangeable potassium content in the surface horizons of a Mollic Cambisol due to biocycling.

Thus, morphology, chemical and physical properties and mineralogical composition of clay fractions of the soils studies support the hypothesis that the soils of the zone constitute a chronosequence.

\section{The Origin of Exposed Surfaces}

The origin of exposed surfaces should be partially ascribed to gully erosion. It is especially intensive during catastrophic climatic events; local people showed the authors a deep gully, which was formed in one day by hurricane Paulina in 1998. However, some "young" soils are situated on moderate slopes (concave, convex, and linear ones) likely due to seismically induced mass wasting, which is a common phenomenon in tectonically unstable areas (Cetin et al. 2004; Chang et al. 2005). As previously mentioned, the pacific coast of Mexico is a seismically active zone (Rojas et al. 1987). The most recent earthquake, in 1999, led to a landslide on the slopes of the Finca Sinai coffee-growing farm.
A few landslide-induced outcrops of parent material can be observed in the area. It is important to note that in the studied zone, landslides occur on the surfaces containing red clayey soils. This corresponds with the data in the literature, which show that mainly deeply weathered soils are subjected to landslides (Dykes 2002), because younger soils are less clayey and have better internal hydraulic conductivity. Earthquake-induced mass wasting may also account for intensive denudation of soil material along the slopes (Wilcke et al. 2003). Thus, the development of soils in the region depends on catastrophic events, which periodically expose fresh surfaces and give rise to incipient soils formation.

Also, formation of soils of different ages on sandy saprolite can be explained by the occurrence of landslide-causing earthquakes and/or hurricanes. Soils formed on the exposed surfaces should have different ages. Unfortunately, it is difficult to establish the absolute age of such events, even though a lot of them have been detected in this region in historical times.

\section{Pedogenesis Model}

The hypothesis that the studied profiles form a chronosequence should be verified. We arranged the soils in a tentative succession from group four (the youngest ones) to group one (the oldest ones). Mainly soil morphology criteria were used for initial arrangement: yellow and brown coloured soils with coarser texture were considered to be the youngest, and red clayey soils were regarded as the oldest. We also hypothesise that base saturation decreases with time because of leaching of bases. We propose a model for the development of soils on exposed surfaces, from highbase to low-base saturated soils, and then ultimately soils with clay-illuviation. General trends in soil properties are presented in Fig. 8. We analysed the changes in soil properties in B horizons (at depth approximately 50-70 cm) in a hypothetical chronosequence (Fig. 8). Clay content increases greatly in the course of soil development (Fig. 8a), cation exchange capacity, recalculated to clay content, decreases (Fig. 8b), organic C increases mainly in the two oldest profiles (Fig. 8c), and $\mathrm{pH}$ values show only a slight trend to decrease with time (Fig. 8d). The increase in organic $\mathrm{C}$ in the Bt horizons of Alisols in combination with the decrease in CEC may seem strange, because organic matter accumulation usually results in an increase in CEC. We ascribed that contradiction to low activity of accumulated organic matter, which may indicate a significant absolute age of red clayey Alisols.

If we consider red clayey Alisols as much older soils are they products of the same route of soil development, or are they the remains of ancient soil formation, which could be completely different from the present one? In other words, are the red clayey soils surface paleosols, or do they fit in the same evolutionary sequence as the other members? The scheme in Fig. 8 supports the hypothesis of a continuous soil evolution. The chronosequence includes soils of different age having different degrees of leaching of bases and clay translocation. The hypothesis is supported, in large part, by the relative uniformity in mineralogical composition of the 
soils studied. Both clayey and sandy soils are dominated by kaolinite minerals and, in most cases, gibbsite. Both groups show, at least in some horizons, the presence of 2:1 minerals.

The model of pedogenesis in the study area is summarised in Fig. 9. Freshly exposed surfaces are occupied by vegetation and incipient soil formation begins. Later on, percolating water and living organisms lead to the formation of a surface humus horizon and subsurface material alteration, thus forming Cambisols. Leaching of bases results in Umbrisol formation. Mineral weathering and clay illuviation finally lead to the formation of soils with argic horizon: Luvisols and Alisols. Further soil development can only be speculated upon. In a stable geomorphological condition they might transform to Acrisols, soils with low-activity clays. However, in the study area, slope processes usually affect these soils. Some of them may be completely destroyed by landslides, giving rise to a new cycle of soil formation. Some of them may be partially truncated (Fig. 9). Independent of the presence of clay skins, truncated soils with no textural differentiation are classified as Cambisols (FAO-ISRIC-ISSS 1998). In most cases, there is evidence of fresh material accumulation on the surface of these soils such as surface horizons with coarser textures, and some layering of surface humus-rich horizons. There are "stone lines" in some profiles. The surface horizons often contain 2:1 minerals in clay fraction, unlike the Bt horizons, where these minerals are almost lacking (Fig. 3). Thus, some complex profiles also occur in the study area.

\section{CONCLUSIONS}

1. Soils of Finca Sinai, a coffee-growing farm in a mountainous region of the state of Oaxaca, Mexico, form a complex mosaic of Alisols, Umbrisols, and Cambisols.

2. The soils studied differ in chemical and physical properties. The clay fraction is dominated by kaolinite and gibbsite in all the soils, the difference between the soils is in the proportion of halloysite and mixed-layered illitevermiculite, which increases from Alisols to Cambisols. Even the most weathered Alisols, with nothing but kaolinite and gibbsite in the clay fraction have relatively high CEC due to the presence of active 2:1 minerals in the silt fraction.

3. Soil properties and classification depend mainly on the age of the soils, which form on the surfaces exposed by periodic intensification of erosion and landslides. The periodicity can be ascribed to mass wasting events induced by hurricanes and earthquakes.

4. We proposed a model for soil development in the study area. The extent of leaching of bases and clay translocation increases with age of surface exposition. According to the proposed scheme, the soils develop from Cambisols to Umbrisols and then to Alisols. The evolutionary sequence is complicated by slope processes, which cause soil truncation and colluvial material accumulation on soil surface.

\section{ACKNOWLEDGEMENTS}

This research received financial support of the Projects UNAM-CONACyT 28227B, SEP-CONACyT 43702, OCI-
UNAM, and SRE for International Cooperation. The authors wish to acknowledge Dr. A. Safronov, Dr. J. B. Dixon and Dr. N. White for XR diffraction facilities; S. Galicia, E. Fuentes and R. Ramos for technical assistance; Professor R. Arnold and Dr. L. Hernández for valuable comments; and D. Wooldrich, the owner of the coffee plantation, for the technical support for the field studies.

Alfaro Sánchez, G. 2004. Suelos. Pages 55-66 in A. J. GarcíaMendoza, M. de Jesús Ordóñez, and M. Briones-Salas, eds. Biodiversidad de Oaxaca. UNAM-FOCN-WWF, México, DF.

Birkeland, P. W. 1999. Soils and geomorphology. 3rd ed. Oxford University Press, New York, NY. 342 pp.

Centeno-García, E. 2004. Configuración geológica del estado. Pages 29-42 in A. J. García-Mendoza, M. de Jesús Ordóñez, and M. Briones-Salas, eds. Biodiversidad de Oaxaca. UNAM - FOCN - WWF, México, DF.

Cetin, K. O., Isik, N. and Unutmaz, B. 2004. Seismically induced landslide at Degirmendere Nose, Izmit Bay during Kocaeli (Izmit)Turkey earthquake. Soil Dynamics and Earthquake Engineering 24: 189-197.

Chang, K. J., Taboada, A. and Chan, Y. C. 2005. Geological and morphological study of the Jiufengershan landslide triggered by the Chi-Chi Taiwan earthquake. Geomorphology (in press).

Cuanalo, C. H. 1975. Manual para descripción de perfiles de suelos en el campo. Colegio de Postgraduados de Chapingo, Estado de México.

Dixon, J. B. 1989. Kaolin and serpentine group minerals. Pages 467-525 in J. B. Dixon and S. B. Weed, eds. Minerals in soil environments. SSSA Book Series:1. ASA, SSSA. Publ., Madison, WI. Dixon, J. B. and White, G. N. 1999. Soil mineralogy. Laboratory manual. Agronomy 626. Soil and Crop Sciences Department, Texas A\&M University, College Station, TX.

Drees, L. R., Wilding, L. P., Owens, P. R., Wu, B., Perotto, H. and Sierra, H. 2003. Steepland resources: characteristics, stability and micromorphology. Catena 54: 619-636.

Dykes, A. P. 2002. Weathering-limited rainfall-triggered shallow mass movements in undisturbed steepland tropical rainforest. Geomorphology 46: 73-93.

FAO-ISRIC-ISSS. 1998. World reference base for soil resources. Soil Resources Report No. 84, Rome, Italy.

Feldman, S. B., Zelazny, L. W. and Baker, J. C. 1991. High-elevation forest soils of the southern Appalachians: I. Distribution of parent materials and soil-landscape relationships. Soil Sci. Soc. Am. J. 55: 1629-1637.

Fuentes Romero, E., García Calderón, N. E. and Krasilnikov, P. V. 2002. Estudio de los nutrientes y características edáficas en cafetales con diferentes grados de apertura del dosel en Pluma Hidalgo, Oaxaca. Café Cacao 3: 61-63.

García, E. 1973. Modificaciones al sistema de clasificación climática de Köppen. UNAM, México, DF.

García Calderón, N. E., Ibañez, A., Fuentes, E., Platero, B., Galicia, M. S., Ramos, R., Mercado, I., Reyes, L., Hernández, A. and Trémols, J. 2000. Características de los suelos de un sector de Pluma Hidalgo, Sierra Sur de Oaxaca, México. Pages 61-67 in R. Quintero Lizaola et al., eds. La edafología y sus perspectivas al Siglo XXI. Tomo I. CP-UNAM-UACh, México, DF.

Ghabru, S. K., Mermut, A. R. and St. Arnaud, R. J. 1987. The nature of weathered biotite in sand-sized fractions of Gray Luvisols (Boralfs) in Saskatchewan, Canada. Geoderma 40: 65-82.

Graham, R. C. and Buol, S. W. 1990. Soil-geomorphic relations on the Blue Ridge Front: II. Soil characteristics and pedogenesis. Soil Sci. Soc. Am. J. 54: 1367-1377. 
Graham, R. C., Daniels, R. B. and Buol, S. W. 1990. Soil-geomorphic relations on the Blue Ridge Front: I. Regolith types and slope processes. Soil Sci. Soc. Am. J. 54: 1362-1367.

Hernández, J. R., Ortiz, M. A. and Zamorano, J. J. 1996. Regionalización morfoestructural de la Sierra Madre del Sur, México. Investigaciones Geográficas 31: 45-67.

Homann, P. S., Solins, P., Chappell, H. N. and Strangenberg, A. G. 1995. Soil organic carbon in a mountainous, forested region: relation to site characteristics. Soil Sci. Soc. Am. J. 59: 1468-1475. Huggett, R. J. 1998. Soil chronosequences, soil development, and soil evolution: a critical review. Catena 32: 155-172.

Hunckler, R. V. and Schaetzl, R. J. 1997. Spodosol development as affected by geomorphic aspect, Borada County, Michigan. Soil Sci. Soc. Am. J. 61: 1105-1115.

Ibáñez, A., Fuentes, E., Alvarez, G. and García, N.E. 2001. Sustancias húmicas en suelos cafetaleros de la finca "El Sinaî", Oaxaca, México. Programas y Resúmenes de XV Congreso Latinoamericano y V Cubano de la Ciencia del Suelo. Boletin de Sociedad Cubana de la Ciencia del Suelo 4: 30.

Kunze, G. W. and Dixon, J. B. 1986. Pretreatment for mineralogical analysis. Pages 91-100 in A. Klute, ed. Methods of soil analysis. Part 1. Physical and mineralogical methods. Agronomy 9. 2nd ed. ASA, SSSA. Publ., Madison, WI.

Krasilnikov, P. V. 2001. Mosaics of the soil cover and species diversity of aboveground vegetation in forest ecosystems of Eastern Fennoscandia. Eurasian Soil Sci. 34 (Suppl. 1): S90-S99.

Kretzschmar, R., Robarge, W. P., Amoozegar, A. and Vepraskas, M. J. 1997. Biotite alteration to halloysite and kaolinite in soil-saprolite profiles developed from mica schist and granite gneiss. Geoderma 75: 155-170.

McBratney, A. B. 1992. On variation, uncertainty and informatics in environmental soil management. Australas. J. Soil Res. 30: 913-935.

McLean, E. O. 1982. Soil pH and lime requirement. Pages 199224 in A. L. Page, R. H. Miller, and D. R. Keeney, eds. Methods of soil analysis. Part 2. Chemical and microbiological properties. Agronomy 9, 2nd ed. ASA, SSSA. Publ., Madison, WI.

Morán, D. J., Corona, P. and Tolson, G. 1996. Uplift and subduction-erosion in southwestern México since Oligocene: pluton barometry constraints. Earth Planetary Sci. Lett. 141: 51-65.
Nelson, D. W. and Sommers L. E. 1982. Total carbon, organic carbon, and organic matter. Pages 539-579 in A. L. Page, R. H. Miller, and D. R. Keeney, eds. Methods of soil analysis. Part 2. Chemical and microbiological properties. Agronomy 9, 2nd ed.ASA, SSSA. Publ., Madison, WI.

Pai, C. W., Wang, M. K., King, H. B., Chiu, C. Y. and Hwong, J.-L. 2004. Hydroxy-interlayered minerals of forest soils in A-Li Mountain, Taiwan. Geoderma 123: 245-255.

Rojas, T. R., Pérez, J. M. and Acosta, G. 1987. "Y volvió a temblar". Cronología de los sismos en México. Cuadernos de la Casachata 13J. Centro de Investigación y Estudios Superiores de Antropología Social: México, DF.

Rutherford, G. K. 1987. Pedogenesis of two Ultisols (Red Earth Soils) on granite in Belize, Central America. Geoderma 40: 225-236.

Rzedowski, J. 1978. Vegetación de México. Limusa, México, DF. Singer, A., Zarei, M., Lange, F. M. and Stahr, K. 2004. Halloysite characteristics and formation in the northern Golan Heights. Geoderma 123: 279-295.

Sparling, G., Ross, D., Trustrum, N., Arnold, G., West., A., Speir, T. and Schipper, L. 2003. Recovery of topsoil characteristics after landslip erosion in dry hill country of New Zealand, and a test of the space-for-time hypothesis. Soil Biol. Biochem. 35: $1575-1586$.

Staver, C. 1998. Managing ground cover heterogenity in coffee (Coffea arabica L.) under managed tree shade: from replicated plots to farmer practice. Pages 67-96 in E. L. Buck, P. J. Lassoie, and C. H. E. Fernandes, eds. Agroforestry in sustainable agricultural systems. CRC Press, Lewis Publ., Boca Raton, FL.

Tan, K. H. 1996. Soil sampling, preparation, and analysis. Marcel Dekker, Inc., New York, NY. 264 pp.

Thomas, G. W. 1982. Exchangeable cations. Pages 159-165 in A. L. Page, R. H. Miller, and D. R. Keeney, eds. Methods of soil analysis. Part 2. Chemical and microbiological properties. Agronomy 9, 2nd ed.ASA, SSSA. Publ., Madison, WI.

Wilcke, W., Valladarez, H., Stoyan, R., Yasin, S., Valarezo, C. and Zech, W. 2003. Soil properties of landslides in mountain rain forest, Ecuador. Catena 53: 79-95. 